\title{
Markery nowotworowe w rutynowej diagnostyce raka nerki
}

\author{
Anna M. Badowska-Kozakiewicz' , Michał P. Budzik²
}

Rak nerki to szczególnie złośliwy nowotwór, który występuje częściej u mężczyzn niż u kobiet i stanowi blisko 90\% wszystkich guzów nerek. Najczęściej występującym rakiem nerki jest rak jasnokomórkowy, stanowiący około 80\% wszystkich przypadków raka nerki.

Wśród markerów diagnostycznych raka nerki, o których mowa w niniejszym artykule, wymienia się najczęściej kwaśne białko immunosupresyjne IAP, którego podwyższony poziom we krwi wskazuje na obecność u chorych przerzutów do węzłów chłonnych lub innych odległych przerzutów. Istotnym markerem w diagnostyce raka nerki jest również glikoproteina P, której zwiększona ekspresja związana jest ze złym rokowaniem. Jako markery zaawansowanego raka nerki badane są także cząsteczki adhezyjne, metaloproteinazy oraz cyklooksygenaza 2. W ostatnim czasie PAX2 okazał się być przydatnym markerem w diagnostyce raka nerki.

Mimo iż w diagnostyce raka nerki stosowanych jest wiele markerów, to żaden z nich nie jest w pełni diagnostyczny, dlatego też diagnostyka oparta na biomerkerach nie może pełnić podstawowego kryterium rozpoznania raka nerki. Może służyć jedynie uzupełnieniu prowadzonej diagnostyki oraz monitorowaniu leczenia i wykryciu ewentualnego nawrotu procesu chorobowego.

Istotne jest dalsze poszukiwanie nowych prognostycznych biomarkerów, które by były odpowiednie w rutynowej diagnostyce tego nowotworu i mogły podnieść efektywność leczenia.

\section{Tumour markers in the routine diagnosis of renal cell carcinoma}

Kidney cancer is a particularly malignant cancer that occurs more often in men than in women and accounts for nearly $90 \%$ of all renal tumours. The most common kidney cancer is clear cell carcinoma, making up approximately $80 \%$ of all cases.

Among the diagnostic markers of kidney cancer, is the most common immunosuppressive acidic protein IAP, whose elevated levels in the blood indicate the presence of lymph node metastases or other distant metastases. Another important marker in the diagnosis of kidney cancer is P-glycoprotein: the increased expression is associated with poor prognosis. Other markers of advanced kidney cancer are also examined: adhesion molecules, matrix metalloproteinases, and cyclooxygenase. It is also noted that 2 PAX2 has recently proved to be a useful marker in the diagnosis of renal cancer.

No markers used are fully diagnostic, therefore such markers cannot act as the primary criterion for the diagnosis of renal cancer. They can be used only as a supplement to other diagnostics used to monitor the treatment and detection of a possible recurrence of the disease. It is important to continue to search for new prognostic biomarkers that can be appropriate for routine diagnosis of this tumour and may increase the effectiveness of treatment.

NOWOTWORY Journal of Oncology 2013; 63, 6: 476-480

Słowa kluczowe: rak nerki, rak jasnokomórkowy, rak brodawkowaty, rak chromofobowy, markery nowotworowe Key words: renal cell carcinoma, clear cell carcinoma, carcinoma papillare, carcinoma chromophobicum, tumour markers 


\section{Charakterystyka raka nerki}

Rak (carcinoma) to nowotwór złośliwy rozwijający się z tkanki nabłonkowej, naśladujący typ nabłonka narządu, w którym się rozwija. Wykazuje cechy różnicowania, dojrzewania i metaplazji. Jednym ze szczególnie złośliwych nowotworów jest rak nerki (carcinoma renis, renal cell carcinoma - RRC). Występuje on częściej u mężczyzn niż u kobiet i stanowi blisko 90\% wszystkich guzów nerek [1]. Liczba zachorowań na nowotwór złośliwy nerki odnotowana w Polsce w roku 2010 wynosiła 2736 u mężczyzn i 1908 przypadków zachorowań u kobiet. Szczyt zachorowalności przypada między 60 a 64 rokiem życia. Nowotwory złośliwe nerek stanowią 3,9\% nowotworów u mężczyzn i 2,7\% - u kobiet. Dotychczasowe badania nie potwierdziły jednoznacznie etiologii raka nerki, ale przynoszą coraz więcej informacji o defektach chromosomowych przyczyniających się do jego rozwoju. Ostatnio opisywane są liczniejsze przypadki zachorowań w młodym wieku oraz po leczeniu cytostatykami i lekami immunosupresyjnymi. Ryzyko wystąpienia raka nerki zwiększa również palenie tytoniu, otyłość, nadciśnienie tętnicze oraz ekspozycja na czynniki chemiczne, głównie nitrozaminy, kadm i arsen [2]. Pojawiają się również dane, że czynnikiem podnoszącym ryzyko zachorowania jest przewlekła dializoterapia [3]. Rak nerki daje przerzuty do płuc i kości, rzadziej do wątroby, nadnerczy, mózgu i drugiej nerki. Najbardziej charakterystyczną cechą biologiczną tego nowotworu jest nieprzewidywalność jego przebiegu klinicznego. Często zdarza się, że dopiero odległe przerzuty są pierwszym objawem choroby [4].

Najczęściej występującym rakiem nerki jest rak jasnokomórkowy (carcinoma clarocellulare; clear cell carcinoma), zwany również rakiem konwencjonalnym (convencional cell carcinoma), stanowiący około $80 \%$ wszystkich przypadków raka nerki. Jest to rzadki nowotwór wywodzący się z tkanki nabłonkowej proksymalnych odcinków kanalików nerkowych. Rozwija się w korze nerki, częściej w biegunie górnym, osiągając średnicę do kilkunastu centymetrów i jest otoczony torebką łącznotkankową. Często wykazuje tendencje do wrastania do żył nerkowych, czasem wrasta przez żyłę główną dolną aż do prawego przedsionka serca. W niektórych przypadkach rak ten wydziela erytropoetynę i prolaktynę [5], rzadziej stwierdza się wydzielanie parathormonu, witaminy $D$, prostaglandyn, gonadotropiny czy reniny.

Ocena mikroskopowa, morfologiczna, histochemiczna, biochemiczna oraz cytogenetyczna wykazuje, że nie jest to zmiana jednorodna [6]. Histologicznie nowotwór ten składa się z komórek o jasnej lub ziarnistej, kwasochłonnej cytoplazmie. Występuje sporadycznie oraz — rzadziej — w postaci rodzinnej lub jako element zespołu von Hippel-Lindau [7].

Znacznie rzadziej rozpoznawanym rakiem nerki, występującym w około 10-15\% przypadków, jest rak brodawkowaty (carcinoma papillare; papillary renal cell carcinoma), zwany również chromofilnym. Charakteryzuje się on brodawkowatym typem wzrostu, często występuje obustronnie w postaci wielu ognisk. Za rozwój raka brodawkowatego odpowiada protoonkogen MET, który zlokalizowany jest na chromosomie 7q31. Nieprawidłowy rozrost komórek nabłonka kanalikowego, będący prekursorem raka brodawkowatego, jest następstwem nadmiernej liczby kopii MET w wyniku zwielokrotnienia fragmentu chromosomu 7.

Około 5\% przypadków stanowi rak chromofobowy (carcinoma chromophobicum; chromophobe renal cell carcinoma), który swoją nazwę zawdzięcza ciemniejszemu zabarwieniu komórek. Nowotwór ten cechuje się znaczną liczbą delecji w obrębie wielu chromosomów $(1,2,6,10,13,17,21)$ oraz stosunkowo dobrym rokowaniem [3]. Rak chromofobowy powstaje z komórek kanalików wyprowadzających lub ich komórek wstawkowych. W przeciwieństwie do dwóch omówionych wyżej raków występuje z jednakową częstotliwością zarówno u mężczyzn, jak i u kobiet i charakteryzuje się dobrym rokowaniem.

Najrzadziej występującymi (stanowiącymi 1-2\% przypadków) typami raka nerki są: rak z cewek zbiorczych (collecting duct cell carcinoma), różnicujący w kierunku komórek cewek zbiorczych, oraz rak sarkomatoidalny (carcinoma sarcomatoides; sarcomatoid cell carcinoma) charakteryzujący się niskozróżnicowaną budowa komórkową. Rokowanie w przypadku obu typów jest znacznie gorsze niż przy rozpoznaniu raka jasnokomórkowego [4].

\section{Biomarkery nowotworowe}

Markery nowotworowe to wysokocząsteczkowe substancje: białka cytoplazmatyczne, białka powierzchni komórek, hormony, lipidy i enzymy, których zwiększone stężenie w organizmie może świadczyć o szerzącym się procesie chorobowym. Markery są najczęściej produktami komórek nowotworowych, ale mogą powstawać również w prawidłowych komórkach organizmu w odpowiedzi na pojawienie się nowotworu. Są uwalniane do płynów ustrojowych lub pozostają jako znaczniki na powierzchni produkujących je komórek. Podwyższenie poziomu markerów we krwi jest oznaką pozwalającą na wykrycie nowotworu oraz może być przejawem nawrotu procesu chorobowego, który ujawnia się wcześniej niż w innych badaniach diagnostycznych. Pozwala również na monitorowanie skuteczności leczenia operacyjnego, jak również chemioterapii oraz hormonoterapii. Ocena poziomu niektórych markerów pozwala także na określenie rokowania [8]. Należy jednak zwrócić uwagę na fakt, że większość markerów nowotworowych nie jest specyficzna. Oznacza to, że ich podwyższone stężenie może towarzyszyć również zmianom niezłośliwym. Możliwa jest również sytuacja, w której choroba nie powoduje wzrostu stężenia markerów, o czym należy pamiętać w diagnostyce raka nerki [9]. Markery nowotworowe oznacza się na komórkach pierwotnej masy guza, w komórkach przerzutów 
i w płynach ustrojowych (surowicy krwi, wysiękach) oraz w moczu. W celu klasyfikacji podzielono je na trzy grupy, które charakteryzują: biologię nowotworu, wielkość i stadium rozwoju guza oraz odpowiedź organizmu na wystąpienie patologicznej zmiany [10]. Markery nowotworowe są wykrywane poprzez zastosowanie technik immunohistochemicznych. Czasem przybierają postać receptorów błonowych, które mogą stanowić ważny cel chemioterapii. Białka produkowane w fazie S i G2 cyklu komórkowego (Ki-67, DcNa) mogą służyć do oznaczenia wskaźnika prognostycznego. Inne regulują cykl komórkowy, apoptozę lub są produktami onkogenów [11].

\section{Markery diagnostyczne raka nerki}

Wyniki badań nad markerami raka nerki oraz ich specyficznością pojawiły się już w ostatnich kilkudziesięciu latach ubiegłego stulecia. Udało się między innymi zaobserwować, że u około 35-70\% chorych występuje podwyższone stężenie ferrytyny w surowicy krwi [12]. Opisano również przypadki wzrostu stężenia CEA, CA 15-3, CA-125, CA 19-9, jednak miały one miejsce znacznie rzadziej. Wnioski te nie pozwoliły na wykorzystanie wymienionych substancji w prognozowaniu i monitorowaniu przebiegu klinicznego raka nerki, ponieważ wykazały one zbyt niską czułość i specyficzność w przebiegu tego nowotworu. W niektórych przypadkach w ogóle nie odnotowano podwyższenia ich stężenia u pacjentów ze zdiagnozowanym rakiem nerki. Istnieją również dane na temat zmian w obrębie chromosomów, polegających przede wszystkim na translokacji t $(3 ; 6), \mathrm{t}(3 ; 8)$ i t $(3 ; 5)$ oraz pojawieniu się nadliczbowych kopii chromosomów 8, 17 i delecji w obrębie 17p, 18p, 3p. Zauważono także nieprawidłową aktywację protoonkogenów, inaktywację genów supresorowych oraz zaburzenia ekspresji czynników wzrostu, jednak również nie były one charakterystyczne dla nowotworu nerki. Wyniki potwierdziły jedynie teorię, iż rozwój nowotworu nie zachodzi pod wpływem zmiany pojedynczej, lecz wielu zmian w materiale genetycznym [13].

Stale pojawiają się wyniki badań, których celem jest poszukiwanie nowych czynników rokowniczych raka nerki. Już w połowie lat osiemdziesiątych Ljungberg i wsp. (1985) opisali zależność między ploidią DNA komórek nowotworowych a stopniem jego rozwoju, histologicznej złośliwości, aktywności proliferacyjnej i reakcji na stosowane leczenie. Według autorów guzy z przewagą diploidalnego DNA charakteryzują się wzrostem miejscowym, w przeciwieństwie do nowotworów z przewagą komórek aneuploidalnych, wykazujących tendencję do naciekania miejscowego i tworzenia odległych przerzutów [14].

Opisanym wielokrotnie czynnikiem rokowniczym w nowotworach złośliwych, w tym również w raku nerki, jest także kwaśne białko immunosupresyjne (IAP). Jego znacznie podwyższony poziom we krwi wskazuje na obecność u chorych przerzutów do węzłów chłonnych lub innych odległych przerzutów. Wzrost stężenia jest zdecydowanie mniejszy w przypadku szerzenia się miejscowego procesu chorobowego [15].

Badając markery prognostyczne w nowotworach, zwraca się w ostatnich latach uwagę na rolę glikoproteiny $\mathbf{P}$ (P-gp). Białko to należy do transporterów ABC (ATP-binding cassettes), które do usuwania substancji z wnętrza komórki, w tym leków chemioterapeutycznych, wykorzystują energię z hydrolizy ATP. Wyniki ostatnich badań nad mechanizmami oporności wielolekowej wskazują nadmierną ekspresję glikoproteiny $\mathrm{P}$ jako główną przyczynę prowadzącą do transformacji nowotworowej oraz dowodzą, że zwiększona ekspresja P-gp źle rokuje w wielu rodzajach nowotworów. Glikoproteina P występuje jednak nie tylko w komórkach zmienionych przez proces nowotworowy. Jej obecność stwierdzono w tkankach budujących narządy o funkcjach wydzielniczych, przede wszystkim jest jednak obecna w tkankach nerki. Ta cecha powoduje, że komórki raka nerki są szczególnie oporne na leczenie. Poprzez stały transport chemioterapeutyków poza komórkę białko to uniemożliwia ich akumulację w cytoplazmie i osiągnięcie przynoszącego efekt stężenia [16].

Dirim i wsp. (2008) przeprowadzili ocenę wartości prognostycznej śródbłonkowego czynnika wzrostu (VEGF), cyklooksygenazy-2 (COX-2) i jądrowego antygenu proliferacji (PCNA) w różnych typach histologicznych raka nerki. Autorzy badań stwierdzili wyraźne różnice ekspresjiVEGF i COX-2 w przypadku różnych typów nowotworów, przy czym rak brodawkowaty w porównaniu z rakiem jasnokomórkowym charakteryzował się o wiele większym stopniem ekspresji [17].

Jako potencjalne biomarkery zaawansowanego raka nerki badane są cząsteczki adhezyjne, odpowiedzialne za przyleganie do siebie komórek. Defekty DNA obejmujące geny kodujące te białka są odpowiedzialne za utratę przyczepności pomiędzy różnymi komórkami nowotworowymi, a także między tymi komórkami i istotą międzykomórkową. Prowadzi to do przemieszczania się komórek nowotworowych wewnątrz organizmu i tworzenia często bardzo odległych przerzutów. Wykazano, że ekspresja nabłonkowej cząsteczki adhezji międzykomórkowej (EpCAM) oraz cząsteczki adhezji komórek naczyniowych 1 (VCAM-1) wiąże się z korzystniejszym rokowaniem w raku nerki, podczas gdy ekspresja cząsteczki adhezji międzykomórkowej L1 (L1CAM) oraz cząsteczki adhezji międzykomórkowej EphA2 związana jest z zaawansowaną chorobą i zmniejszoną szansą na przeżycie. Wątpliwa natomiast wydaje się być rola glikoproteiny CD44 w określaniu rokowania i stopnia zaawansowania procesu chorobowego. Utrata przyczepności komórek nowotworowych może być również związana z nieprawidłowościami metabolicznymi obejmującymi substancję międzykomórkową.

Przydatnymi markerami biodegradacji macierzy zewnątrzkomórkowej są w tym przypadku metaloproteinazy 
ulegające nadekspresji w przebiegu nowotworów. Są to enzymy proteolityczne zależne od cynku, należące do endopeptydaz, które w warunkach patologicznych niszczą składniki substancji międzykomórkowej i błon podstawnych, umożliwiając tym samym wzrost guza i jego dalszą inwazję oraz tworzenie przerzutów [18]. Opublikowane ostatnio wyniki badań Ronkainen i wsp. (2012) dostarczają informacje na temat nowych substancji, mogących być biomarkerami raka nerki. Jedną z nich jest wspomniana wcześniej cyklooksygenaza 2. Jest to enzym indukujący powstanie lokalnych informatorów komórkowych w odpowiedzi na stan zapalny. Naukowcy dowiedli, że jego ekspresja w raku nerki jest indukowana przez cytoplazmatyczny czynnik HuR i stanowi znacznik związany ze zmniejszoną przeżywalnością w raku nerki. Podobne cechy wykazała ekspresja cytoplazmatycznej miozyny VI w komórkach nerki zmienionych nowotworowo. Wśród innych typów miozyn wyróżnia ją unikalna możliwość poruszania się w „kierunku minus" włókna aktynowego. Miozyna VI pełni rolę w różnych procesach komórkowych: endocytozie, sekrecji, proliferacji, różnicowaniu i migracji komórek, aktualny stan wiedzy nie pozwala jednak sprecyzować jej roli w indukcji transformacji nowotworowej, czego przyczyną może być bardzo złożony system interakcji tego białka z innymi cząsteczkami [19]. Jako potencjalny marker raka nerki wskazany został również receptor TLR9 (CD289), należący do rodziny receptorów TLR, odgrywających kluczową rolę w uznaniu patogenu i aktywacji odporności wrodzonej, ponadto często ulegający ekspresji w nowotworach nerki. Nie wykazano jednak jego zależności między etapem rozwoju raka i jego typem [20].

Pożądaną metodą wykrywania lub oceny efektywności leczenia nowotworu byłaby możliwość określenia obecności specyficznych markerów w produktach wydalanych przez nerki. Niestety, istnieją tylko nieliczne znane markery raka nerki obecne w moczu. Najlepiej poznanym jest białko NMP22, wykorzystywane powszechnie w diagnostyce raka pęcherza moczowego. NMP22 (Nuclear Matrix Protein 22) jest białkiem tworzącym wewnętrzne rusztowanie jądra komórkowego, związanym z replikacją DNA i syntezą RNA, regulatorem procesu mitozy. Występuje w niewielkich ilościach w moczu osób zdrowych. Zwiększone stężenie zaobserwowano głównie u ludzi cierpiących na raka wywodzącego się z nabłonka przejściowego, ale ostatnio zauważono również jego obecność w raku nerki. Wykrycie w moczu białka NMP22 oparte jest na metodzie immunoenzymatycznej z użyciem dwóch rodzajów przeciwciał monoklonalnych [21, 22].

Pod kątem użyteczności w diagnostyce badany od niedawna jest czynnik PAX2. Jest on jądrowym czynnikiem transkrypcyjnym niezbędnym do płodowego rozwoju nerek, mózgu i oczu. W zdrowych tkankach nerki jego ekspresja została odnotowana tylko w podocytach i komórkach dystalnych części nefronu. Ostatnio PAX2 okazał się być dobrym markerem raka nerki, prezentującym kilka zalet. Przede wszystkim wykrywany jest on w dużym odsetku przypadków raka nerki i niezależnie od typu nowotworu, co pozwala na dokładną lokalizację procesu chorobowego podczas kontrolnych badań [23].

Obecnie nie ma testu diagnostycznego pozwalającego na odpowiednio wczesne rozpoznanie raka nerki, a przeważająca część guzów jest wykrywana przypadkowo podczas rutynowych badań USG. Morrissey i wsp. (2009) określili dwa białka wydalane z moczem: akwaporynę-1 oraz adipofilinę, które mogą stać się kluczowymi markerami pozwalającymi na wczesne wykrycie raka nerki. Zauważyli, że ilość wydalanych z moczem białek jest znacznie większa u chorych na raka nerki niż u osób zdrowych orazże ściśle koreluje ze stadium rozwoju i wielkością guza. Odnotowali także zmniejszenie ich zawartości w moczu po chirurgicznym usunięciu nerki ze zmianą nowotworową [24]. Jest to jednak odkrycie nowe, wymagające jeszcze wielu badań, choć stwarza perspektywy szybkiej i nieinwazyjnej diagnostyki.

Badania markerów raka nerki w ostatnich latach skupiają się również wokół aktywności wydzielniczej nowotworów. Chociaż aktywność neuroendokrynna jest od dawna przypisywana komórkom raka nerki, badane markery tj. serotonina, CD56, swoista enolaza neuronowa NSE, chromogranina A i synaptofizyna wydają się nie spełniać kryteriów, które są stawiane potencjalnym markerom prognostycznym [25].

\section{Podsumowanie}

Rozpoznanie raka nerki i jego umiejscowienia odbywa się najczęściej podczas rutynowych badań ultrasonograficznych, podczas których możliwe jest wykrycie małych zmian, już powyżej $0,5 \mathrm{~cm}$. Badanie to pozwala również na różnicowanie zmian litych od torbieli prostych i wielokomorowych. Na dokładniejszą ocenę położenia guza i stanu zaawansowania procesu nowotworowego pozwala tomografia komputerowa. Opcjonalnym, choć coraz rzadziej wykorzystywanym badaniem jest w tym przypadku również angiografia, uwidaczniająca patologiczne unaczynienie w rejonie zmiany, oraz urografia. Zastosowanie rezonansu magnetycznego ogranicza się do potwierdzenia wątpliwości diagnostycznych [26]. Ostateczne rozpoznanie typu nowotworu przynosi jednak zawsze badanie histopatologiczne pobranej od pacjenta tkanki. Należy pamiętać, że klasyfikacja raka nerki jest bardzo ważna, ponieważ odmienne typy nowotworu cechują się znacząco różnym przebiegiem klinicznym i rokowaniem. Jest ona jednak trudna ze względu na wiele wspólnych cech budowy mikroskopowej. Tu pomocna może być ocena poziomu markerów nowotworowych, która jest niewątpliwie cennym narzędziem mogącym pomóc $w$ diagnostyce raka nerki. Stale prowadzone badania nad identyfikacją nowych markerów pozwalają na określenie wielu parametrów związanych z występowaniem i leczeniem nowotworów. Metoda ta, mimo wielu zalet, nie 
jest jednak całkowicie niezawodna. Obecnie służy raczej do potwierdzenia i wspomagania rozpoznania wielu zmian, niemniej jednak jest to stale rozwijająca się gałąź wiedzy, coraz bardziej wnikająca do praktyki klinicznej i wykorzystywana do diagnostyki, monitorowania i prognozowania przebiegu chorób nowotworowych.

W celu poprawienia efektywności diagnostyki poszukiwane są stale markery nowotworowe, które charakteryzowałyby się:

- dodatnim wynikiem jedynie w przypadku osób chorych,

- występowaniem tylko w przypadku jednego rodzaju nowotworu,

— zależnością stężenia od stadium rozwoju guza [27].

Obecnie jednak żaden ze znanych markerów nowotworowych nie odpowiada w pełni wszystkim tym wyznacznikom, dlatego też diagnostyka oparta na biomerkerach nie może pełnić podstawowego kryterium rozpoznania raka nerki. Może służyć jedynie jako uzupełnienie prowadzonej diagnostyki oraz w celu monitorowania leczenia i wykrycia ewentualnego nawrotu procesu chorobowego. Tradycyjne czynniki prognostyczne nie są wystarczające, by dokładnie przewidzieć kliniczny przebieg raka nerki. Nie poznano dotąd również prognostycznych biomarkerów, które byłyby odpowiednie do stosowania w rutynowej diagnostyce tego nowotworu, jest to jednak konieczne, by podnieść efektywność leczenia.

Dr Anna M. Badowska-Kozakiewicz

Zakład Biofizyki i Fizjologii Człowieka

Warszawski Uniwersytet Medyczny

e-mail:abadowska@wum.edu.pl

Otrzymano: 4 lutego $2013 \mathrm{r}$.

Przyjęto do druku: 27 sierpnia 2013 r.

\section{Piśmiennictwo}

1. Clague J, Lin J, Cassidy A i wsp. Family history and risk of renal cell carcinoma: results from a case-control study and systematic meta-analysis. Cancer Epidemiol Biomarkers Prev 2009; 18: 801-807.

2. Chow WH, Dong LM, Davesa SS. Epidemiology and risk factors for kidney factors. Nat Rev Urol 2010; 7: 245-257.

3. Pascual D, Borque A. Epidemiology of kidney cancer. Adv Urol 2008; doi: 10.1155.2008.782381

4. Chosia M, Domagała W. Choroby nerek. Nowotwory złośliwe. W: Stachura J, Domagała W (red.) Patologia znaczy słowo o chorobie. Tom 2. Wyd. 1. Kraków: Polska Akademia Umiejętności; 2005, s. 916-922.

5. Kruś S, Skrzypek-Fakhoury E. Podłoże morfologiczne chorób nerek. W: Kruś S, Skrzypek-Fakhoury E (red.) Patomorfologia kliniczna. Wyd. 3. Warszawa: Wydawnictwo Lekarskie PZWL; 2007, s. 545-606.
6. Lopez-Beltran A, Cheng L, Vidal A i wsp. Pathology of renal cell carcinoma: an update. Anal Quant Cytol Histol 2013; 35: 61-76.

7. Cotran RS, Rennke H, Kumar V. Nerka i drogi wyprowadzające mocz Nowotwory. W: Kumar V, Cotran R, Robbins S (red.) Patologia. Wyd. 1. Wrocław: Elsevier Urban \& Partner; 2008, s. 615-619.

8. Chosia M, Domagała W. Choroby układu moczowego. Nowotwory nerek W: Domagała W, Chosia M, Urasińska E (red.) Podstawy patologii. Wyd. 1. Warszawa: Wydawnictwo Lekarskie PZWL; 2010, s. 455-457.

9. Świeboda-Sadlej A. Badanie podmiotowe i przedmiotowe w chorobie nowotworowej. Najczęstsze nieprawidłowości laboratoryjne mogące świadczyć o rozwoju nowotworu. W: Frączek M (red.) Podstawy diagnostyki i terapii nowotworów. Wyd. 1. Bielsko-Biała: a-medica press; 2008, s. 47-54.

10. Sharma S. Tumor markers in clinical practice: General principles and guidelines. Indian J Med Paediatr Oncol 2009; 30: 1-8.

11. Bhatt AN, Mathur R, Farooque A i wsp. Cancer biomarkers - Current perspectives. Indian J Med Res 2010; 132: 129-149.

12. Singh KJ, Singh SK, Suri A i wsp. Serum ferritin in renal cell carcinoma: effect of tumor size, volume grade, and stage. Indian J Cancer 2005; 42: 197-200.

13. Koźmińska EM Zastosowanie osiągnięć nauk podstawowych w raku nerki. W: Borkowski A, Czaplicki M (red.) Nowotwory i torbiele nerek. Wyd. 1. Warszawa: Wydawnictwo Lekarskie PZWL; 2002, s. 53-64.

14. Ljunberg B, Sterling R, Roos M. DNA content in renal cell carcinoma with reference to tumor heterogenity. Cancer 1985; 3: 503-508.

15. Masuda H, Kurita Y, Suzuki K i wsp. Predictive value of serum immunosuppressive amid protein for staging renal cell carcinoma: comparison with other tumour markers. Br J Urol 1997; 80: 25-29.

16. Badowska-Kozakiewicz AM. Zjawisko oporności wielolekowej w nowotworach — rola glikoproteiny P. Życie Weterynaryjne 2011; 86: 211-214.

17. Dirim A, Haberal AN, Goren MR i wsp. VEGF, COX-2, and PCNA expression in renal cell carcinoma subtypes and their prognostic value. Int Urol Nephrol 2008; 40: 861-868.

18. Nogueira M, Kim HL. Molecular markers for predicting prognosis of renal cell carcinoma. Urol Oncol 2008; 26: 113-124.

19. Lenartowska M, Walczewski J. Miozyna VI: unikalne białko motoryczne cytoszkieletu aktynowego. Postępy Biochem 2011; 57: 63-73.

20. Ronkainen HL Survival and prognostic factors in renal cell carcinoma. W: Ronkainen HL Novel prognostic biomarkers for renal cell carcinoma. Wyd. 1. OULU: Juvenes Print, Tampere, 2012, s. 29-36.

21. Eichelberg C, Junker K, Ljungberg B i wsp. Diagnostic and prognostic molecular markers for renal cell carcinoma: a critical appraisal of the current state of research and clinical applicability. Eur Urol 2009; 55: 851-863.

22. Lipiński M. Metody diagnostyczne stosowane w rozpoznawaniu raka pęcherza moczowego. Przegląd Urologiczny 2008; 48: 64-72.

23. Ozcan A, Zhai J, Hamilton C i wsp. PAX-2 in the diagnosis of primary renal tumors: immunohistochemical comparison with renal cell carcinoma marker antigen and kidney-specific cadherin. Am J Clin Pathol 2009; 131: 393-404.

24. Morrissey JJ, London AN, Luo J i wsp. Urinary biomarkers for the early diagnosis of kidney cancer. Mayo Clin Proc 2010; 85: 413-421.

25. Ronkainen $\mathrm{H}$, Soini $\mathrm{Y}$, Vaarala $\mathrm{MH}$ i wsp. Evaluation of neuroendocrine markers in renal cell carcinoma. Diagnostic Pathology 2010; 5: 28. doi: 10.1186/1746-1596-5

26. Borkowski A, Dobroński P, Demkow T i wsp. Nowotwory nerek i narządów układu moczowo-płciowego. W: Borkowski A (red.) Urologia. Podręcznik dla studentów medycyny. Wyd. 2. Warszawa: Wydawnictwo Lekarskie PZWL; 2006, s. 121-166.

27. Vaidyanathan K, Vasudevan DM. Organ Specific Tumor Markers: What's New? Indian J Clin Biochem 2012; 27: 110-120. 